УДК 336.2: 339.9

E62, H20, H30

\title{
ШЛЯХ СВРОІНТЕГРАЦЇ̈ УКРАЇНИ - ПОДАТКОВЕ РЕФОРМУВАННЯ
}

\section{Хорошилова І.О. кандидат економічних наук}

\section{Харківський національний автомобільно-дорожнній університет}

Постановка проблеми. За останні роки ідея євроінтеграції стала дуже актуальною та має велику підтримку в українському суспільстві. Євроінтеграція набула значення не лише головного зовнішньополітичного пріоритету, але й стала пріоритетним напрямом внутрішньої політики України.

Варто зазначити, що на сьогодні в Україні діє податкова система, яка за своєю структурою подібна до податкових систем розвинених європейських країн, оскільки всі закони, що торкаються оподаткування, розроблено 3 урахуванням норм європейського податкового законодавства. [1] Однак, на відміну від країн $Є С$, податкова система України не $\epsilon$ інструментом підвищення конкурентоспроможності держави, вона не сприяє зростанню економічної активності суб'єктів господарювання. Протягом багатьох десятиріч формувалась існуюча нині система оподаткування України, але з подальшим розвитком ринкових відносин та перетворень все на явніше відображаються існуючі в ній недоліки. Податкова система України та відповідно й механізм нарахування та стягнення податків не стимулюють до розвитку вітчизняного підприємництва, а існуюча податкова система не тільки не заохочує, а й навіть прямо перешкоджає підприємствам розвивати виробництво і підвищувати його рентабельності, що суперечить цілям економічного розвитку держави. [2] Наприклад існують неузгодженості та протиріччя окремих норм податкових законів, їх нестабільність, безсистемне надання пільг та перекручування суті окремих видів податків. Не секрет, що й податковий тиск на платників податків сьогодні вже необхідно знижувати, бо на наш погляд все це поступово спричинило виникнення податкової заборгованості, найбільший податковий 
тягар покладено на законослухняних платників як слідство нерівномірного податкового навантаження. Все це наслідки недосконалості, нестабільності законодавчої бази та сугубо фіскальний характер податкової політики.

Аналіз останніх досліджень і публікацій. Серед відомих учених, які приділяли увагу питанням економічної сутності податків та принципам побудови податкових систем слід згадати А. Ауербаха, Т. Гоббса, А. Сміта, Д. Рікардо, Л. Штейна, А. Вагнера, Д. Мілля, П. Самуельсона, А. Лаффера, О. Болтенко [3] В. Лебедєва, I. Озерова та ін. В українському науковому просторі заслуговують на увагу праці таких вітчизняних вчених: Г. Тарасюка, С. Юрій [1], А. Соколовської, О. Соскіна [4], К. Ковальчука, Т. Лебеди, А. Поддєрьогіна, В. Вишневського, О. Атаманчука та інших.

Невирішені складові загальної проблеми. Варто зазначити, що недостатньо уваги науковцями приділялося порівнянню податкової система України з податковими системами країн Євросоюзу та інших розвинених країн. Крім того, недостатньо досліджені питання напрямів інтеграції податкової системи України до європейського економічного простору.

Формулювання цілей статі. Мета нашого дослідження полягає у висвітленні сучасних моделей європейського законодавства 3 питань оподаткування та законодавства України, дослідженні існуючої податкової системи, виявленні іiі недоліків та переваг, та визначенні пріоритетних завдань перспективи європейської інтеграції. За для цього потрібно дослідити доцільність та прорахувати ефективність реформування податкової системи.

Методика дослідження: аналізуючи, порівнюючи, систематизуючи i узагальнюючи наукові праці багатьох учених, обгрунтуємо та окреслимо зміни податкового законодавства України в умовах євроінтеграції, для цього вдамося до економіко-статистичних методів, порівняльного аналізу

Виклад основного матеріалу дослідження. Як уже відмічалось, зараз стан національної податкової системи далеко не ідеальний, він не відповідає запитам та можливостям суспільства, що свідчить про необхідність здійснення кардинальних реформ. [5]. Податкова система, повинна бути інструментом 
регулювання економіки в руках держави, за іiі допомогою держава повинна стимулювати й контролювати соціально-економічні процеси, виконувати відповідні соціальні, гуманітарні та інші функції. Розвинутими державами для регулювання економічного розвитку застосовуються такі засоби: зміна податкових ставок та податкової бази шляхом розширення переліку доходів; зміна політики акцизів; зменшення соціальних відрахувань; зміна амортизаційної політики; уведення податкових пільг для наново створюваних підприємств та для суб’єктів середнього і малого підприємництва тощо [8].

Виділимо основні недоліки податкової системи України:

- на відміну від країн СС, податки не $\epsilon$ інструментом підвищення конкурентоспроможності держави;

- недосконалість і нестабільність законодавства. Податкове законодавство має схожі риси з європейським законодавством, але тільки в назвах податків. Неоднозначність тлумачення податкового законодавства негативно позначається на діяльності суб’єктів господарювання, знижує привабливість для інвесторів.

- не ефективність системи спрощеного оподаткування, що призводить до зниження мотивації підприємницької діяльності. Світовий досвід i практика показують, що ефективність досягається у взаємодії великих, середніх і малих;

- завеликі витрати на адміністрування податкової системи. Відсутність узгодженості між службами та органами, копіюваня функцій та інше;

- система митно-тарифного регулювання не дає змоги оперативно реагувати на зміни кон'юктури ринку;

- неефективний механізм розподілу податкових надходжень між центральним і місцевими бюджетами гальмує розвиток економіки в областях [7]. 3 огляду на вищезазначене, вважаємо, що чинну податкову систему потрібно не реформувати, а трансформувати, а саме слід посилити соціальну справедливість. Дослідивши позитивний досвід країн-членів ЄС, виділимо 
основні напрямки трансформації податкової політики України: впровадження норм ЄC в національну правову систему; запровадити відповідно до європейських стандартів структуру за видами податків; забезпечити ефективність адміністрування податків. Проте варто наголосити, що при формування і реалізації податкової політики не повинно бути точного копіювання досвіду окремих країн світу, оскільки не можна накладати податкову систему будь-якої країни на нашу дійсність [6, с. 78]. Не варто приймати рішення не обміркував їх та не приміряв до реалій нашої країни, кожен крок у податковому законодавстві повинен бути чітко обгрунтованим, логічним, доступним для розуміння і прийматися тільки у тому випадку, коли доведено економічний ефект від такої новації та проведено глибокий i грунтовний аналіз ефекту від його застосування. На превеликий жаль, на сьогоднішній день функціонування податкової системи не можна порівняти 3 жодною європейською державою ні за одним 3 показників, ні за економічним розвитком, ні за рівнем корупції, ні за рівнем тіньової економіки та іншими. Ефективність податкової системи оподаткування в Україні попре те що має тенденцію до збільшення, але $\epsilon$ нижчою від країн Євросоюзу. Зокрема, якщо проаналізувати наприклад оподаткування доходів громадян в порівнянні 3 обсягами ВВП, то в Україні цей показник дорівнює лише 3,8\%, проте як в країнах ЄС цей показник становить 8,8\%. Ця тенденція спостерігається й стосовно інших податків, зокрема сума ПДВ, зібраного в Україні з вітчизняних товарів, становила 5,5\% ВВП, а в країнах Євросоюзу - відповідно 7,7\% [8, c.114]. До того ж не можемо не погодитись 3 твердженням, що на сам перед потрібно докорінно змінити внутрішню політику, адже на їі основі формуються зовнішньоекономічні напрями розвитку держави. У більшості країн із розвиненою економікою чисельність середнього класу становить близько $60 \%$ населення, у той час, коли в Україні цей показник складає близько $12 \%$, а це той прошарок суспільства, який формує державний та місцеві бюджети, бо саме на середній клас припадає основна частка доходів країни [6]. Адже законодавство, податковий кодекс, фіскальна політика та інші несприятливі 
умови в прямому сенсі «душать» середніх та малих підприємців, та як наслідок бізнес йде в «тінь». Згідно даних Міністерства економічного розвитку i торгівлі України за 2018 рік, розмір тіньової економіки складає 33\% від рівня ВВП країни. А саме детінізація є запорукою збільшення дохідної частини бюджету, адже тіньовий сектор не сплачує податків і фактично паразитує на «офіційному» сегменті. Та найбільшою проблемою нашої податкової системи є iï залежність від балансу політичних сил в економіці, оскільки великий бізнес, який встановлює правила гри, намагається не допустити зменшення своєї частки у створюваній вартості та перерозподілу багатств через оподаткування. Уникнути цього можна тільки змінивши політичну систему України 3 залученням незаангажованих найманих працівників. Тож чекаємо позитивних змін від реформування, початок покладено, в найближчий час запрацюють зміни в оподаткуванні прибутку податком на виведений капітал. Зараз сплачують податок з операційного прибутку (18\%), то з нового року податком в 15\% буде обкладатись дивіденди, а фінансові послуги, інвестування в закордонні підприємства зі ставкою 20\%. За задумом, це має спростити адміністрування податку й заохотити власників вкладати кошти у розвиток виробництва.

Висновки 3 проведеного дослідження. Офіційно, активна фаза податкової реформи в нашій країні триває 3 моменту прийняття Податкового кодексу, але, по факту Українська модель податкових відносин продовжує орієнтуватися на прибуткову складову, а не на споживання, а адміністрування та відшкодування податку продовжують залишатися неефективними i непрозорими. В Україні, на відміну від більшості країн Європи 3 прогресивними ставками податків, діє пласка система оподаткування («flat rate»). Оскільки основні податки, які наповнюють бюджет: - прямі податки зі ставкою 18\% (податок на прибуток та доходи фізичних осіб); - непрямі податки, закладені в ціну продукції, яку ми споживаємо (акцизний збір, ПДВ). Як бачимо, основний податковий тягар в Україні лягає на плечі кінцевих споживачів через акцизні збори, податки на додану вартість та податки 3 
доходів фізичних осіб. Тому податкова система України потребує негайного реформування, спрямованого на вдосконалення інституціональних умов оподаткування, а також вдосконалення структури податкової системи та окремих іiї елементів відповідно до європейських стандартів. Найвагомішим фактором набуття Україною членства в Європейському Союзі є форсоване впровадження ринкових перетворень в країні. За для цього необхідне реформування системи оподаткування в напрямі посилення соціальноорієнтованої конкурентоспроможної ринкової економіки та інтеграції у СС.

\section{Перелік посилань}

1. Юрій С. М. Податкова система України: становлення та розвиток. Чернівецький торговельно-економічний інститут Київського національного торговельно-економічного університету. Ч ІІ. 2013. С. 1-5.

2. Скрипниченко М. І., Лебеда Т. Б., Авксєнтьєв М. Ю., Сембер С. В. Оцінка впливу бюджетно-податкової політики на динаміку макроіндикаторів економіки України. Математичне моделювання в економіці. Збірник наукових праць. Київ. 2013. № 1(3). С. 129-146.

3. Болтенко О. А. Налоговые меры Великобритании по борьбе с финансовым кризисом. Виступ на II Міжнародному науково-практичному симпозіумі по актуальним проблемам податкової політики 16 квітня 2009 року.: сайт. URL : http://www.palata-nk.ru/php/content.php?id=2650\&pr=print. (дата звернення: 2.11.2018).

4. Соскін О. І. Трансформація податкової системи в контексті формування сучасної економічної моделі України. Журнал «Економічний часопис-XXI». 2010. № 34. С. 7-14.

5. Крисоватий А. І., Мельник В. М. Податкові трансформації в СС та податкова політика України в контексті євроінтеграції: монографія. Тернопіль: THEУ, 2014. 236 c.

6. Крисоватий А. I, Федосов В., Яренко Г. Оподаткування багатства: виклик для України. Журнал європейської економіки. 2015. № 2. Т. 14. С. 183205. 
7. Швець Ю. О., Завальнюк А. О. Податкові реформи в країнах ЄС: переваги, недоліки їх впровадження в податкову систему України. Європейський вектор економічного розвитку. 2016. №2 (21). С. 126-134.

8. Мельник В. М., Кощук Т. В. Сучасні податкові реформи у нових країнах - учасницях ЄС. Економіка і прогнозування. 2012. № 3. С 102 - 117.

9. Про внесення змін до Податкового кодексу України щодо покращення інвестиційного клімату в Україні Верховна Рада України; Закон від 21.12.2016 № 1797-VIII. 8. Податковий кодекс України Верховна Рада України; Кодекс України, Закон, Кодекс від 02.12.2010 № 2755-VI.

10. Про внесення змін до Податкового кодексу України та деяких законодавчих актів України щодо забезпечення збалансованості бюджетних надходжень у 2018 році. Верховна Рада України; Закон від від 07.12.2017p. № 2245 - VIII.

\section{References}

1. Yurii, S. M. (2013), The Tax System of Ukraine: Establishment and Development [Podatkova systema Ukrainy: stanovlennia ta rozvytok], Chernivtsi Trade and Economic Institute of Kyiv National Trade and Economic University, Ch. II, P. 1-5.

2. Skrypnychenko, M. I., Lebeda, T. B., Avksientiev, M. Yu., Sember, S. V.. (2013), Estimation of the impact of fiscal policy on the dynamics of macroindicators of the Ukrainian economy [Otsinka vplyvu biudzhetno-podatkovoi polityky na dynamiku makroindykatoriv ekonomiky Ukrainy], Mathematical modeling in economics, Collection of scientific works, Kiev, No 1 (3), P. 129-146.

3. Boltenko, O. A. (2009), Tax measures of Great Britain to combat the financial crisis [Nalogovye mery Velikobritanii po bor'be s finansovym krizisom], Speech at the II International Scientific and Practical Symposium on topical issues of tax policy April 16, available at: http://www.palatank.ru/php/content.php?id=2650\&pr=print. (last accessed: 2.11.2018).

4. Soskin, O. I., (2010), Transformation of the tax system in the context of the formation of a modern economic model of Ukraine [Transformatsiia podatkovoi 
systemy v konteksti formuvannia suchasnoi ekonomichnoi modeli Ukrainy], Journal "Economic Journal-XXI", No 34, P. 7-14.

5. Krysovatyi, A. I., Melnyk, V. M. (2014), Tax Transformations in the EU and Ukraine's Tax Policy in the Context of Eurointegration [Podatkovi transformatsii $v$ YeS ta podatkova polityka Ukrainy $v$ konteksti yevrointehratsii], Monograph, Ternopil: TNEU, $236 \mathrm{p}$.

6. Krysovatyi, A. I, Fedosov, V., Yarenko, H. (2015), Taxation of wealth: a challenge for Ukraine [Opodatkuvannia bahatstva: vyklyk dlia Ukrainy], Journal of the European Economy, No 2, T. 14, P. 183-205.

7. Shvets, Yu. O., Zavalniuk, A. O. Shvets, Yu. O., Zavalniuk, A. O. (2016), Tax reforms in EU countries: advantages, disadvantages of their introduction into the tax system of Ukraine [Podatkovi reformy v krainakh YeS: perevahy, nedoliky yikh vprovadzhennia $\mathrm{v}$ podatkovu systemu Ukrainy], European vector of economic development, No 2 (21), P. 126-134.

8. Melnyk, V. M., Koshchuk, T. V. (2012), Modern tax reforms in the new EU member states [Suchasni podatkovi reformy u novykh krainakh - uchasnytsiakh YeS], Economics and Forecasting, No 3, P. 102-117.

9. On Amendments to the Tax Code of Ukraine on Improving the Investment Climate in Ukraine The Verkhovna Rada of Ukraine (2011), [Pro vnesennia zmin do Podatkovoho kodeksu Ukrainy shchodo pokrashchennia investytsiinoho klimatu $v$ Ukraini Verkhovna Rada Ukrainy], Law dated December 21, No 1797-VIII. 8. The Tax Code of Ukraine The Verkhovna Rada of Ukraine, Code of Ukraine, Law, Code of 02.12.2010 No 2755-VI.

10. On Amendments to the Tax Code of Ukraine and certain legislative acts of Ukraine on ensuring the balance of budget revenues in 2018 [Pro vnesennia zmin do Podatkovoho kodeksu Ukrainy ta deiakykh zakonodavchykh aktiv Ukrainy shchodo zabezpechennia zbalansovanosti biudzhetnykh nadkhodzhen u 2018 rotsi], Verkhovna Rada of Ukraine, Law from 07.12.2017, No 2245 - VIII. 


\section{РЕФЕРАТИ РЕФЕРАТЫ ABSTRACTS}

\section{Хорошилова І.О. ШЛЯХ ЄВРОІНТЕГРАЦІї УКРАЇНИ - ПОДАТКОВЕ РЕФОРМУВАННЯ}

Mema нашого дослідження полягає у висвітленні сучасних моделей європейського законодавства з питань оподаткування та законодавства України та визначенні пріоритетних завдань на перспективу стосовно трансформації податкової системи в контексті європейської інтеграції.

Методика дослідження: аналізуючи, порівнюючи, систематизуючи i узагальнюючи наукові праці багатьох учених, обгрунтуємо та окреслимо зміни податкового законодавства України в умовах євроінтеграції, для цього вдамося до економіко-статистичних методів, порівняльного аналізу. Результати дослідження: проаналізовано сучасний стан і вади вітчизняної моделі податкових відносин України, визначено основні напрямки ії реформування та вдосконалення. 3 огляду на підписання Угоди про асоціацію України i Європейського Союзу, що є великим досягненням та кроком перетворень та економічного розвитку. Але економічна інтеграція та зближення 3 СС вимагають від країн-претендентів на вступ виконання цілої низки вимог, однією 3 яких $\epsilon$ проведення податкових реформ 3 метою гармонізації внутрішніх податкових правил i законів із європейськими стандартами та нормами. Досліджені гострі проблеми у фіскальній системі, а саме, обмеження фінансування соціальної сфери, часте внесення змін у законодавчі акти, перешкоди, обмеження, заборони на здійснення підприємницької діяльності, високий рівень корупції. Наукова новизна: окреслені напрями оптимізації оподаткування України, а саме збільшення ролі держави в управлінні та регулюванні власними фінансовими ресурсами, збільшення обсягів ВВП, що дадуть змогу створити сучасну конкурентну, соціальну-орієнтовану ринкову економіку та прискорити євроінтеграцію. Практична значущість: таким чином, ефективна система державних фінансів, що $\epsilon$ одним із головних чинників динамічного розвитку економіки формує сприятливе макроекономічне середовище для підприємницької діяльності та інвестицій, а також забезпечить належну систему соціального захисту населення.

Ключові слова: податки, податкова система, податкова політика, податкове навантаження, реформування системи оподаткування, європейська інтеграція.

ХорошиЛова И. А. ПУТЬ ЕВРОИНТЕГРАЦИИ УКРАИНЫ НАЛОГОВОЕ РЕФОРМИРОВАНИЕ

Цель нашего исследования заключается в освещении современных моделей европейского законодательства по вопросам налогообложения и законодательства Украины и определении приоритетных задач на перспективу относительно трансформации налоговой системы в контексте европейской интеграции. Методика исследования. Анализируя, сравнивая, систематизируя и обобщая научные труды многих ученых, было обосновано и обобщенно изменения налогового законодательства Украины в условиях евроинтеграции, 
для этого удадимся к экономико статистических методов, сравнительного анализа. Pезультаты. В статье проанализировано современное состояние и недостатки отечественной модели налоговых отношений Украины, определены основные направления ее реформирования и совершенствования. Учитывая подписания Соглашения об ассоциации Украины и Европейского Союза, что является большим достижением и шагом преобразований и экономического развития. Но экономическая интеграция и сближение с EC требуют от странпретендентов на вступление выполнения целого ряда требований, одним из которых является проведение налоговых реформ с целью гармонизации налогового законодательства с европейскими стандартами и нормами. Исследованы острые проблемы в фискальной системе, а именно, ограничение финансирования социальной сферы, частое внесение изменений, в законодательные акты, препятствия, ограничения, запрещения, на осуществление предпринимательской деятельности, высокий уровень коррупции. Научная новизна. Обозначены направления оптимизации налогообложения Украины, а именно увеличение роли государства в управлении и регуляции собственными финансовыми ресурсами, увеличение объемов ВВП, что позволит создать современную конкурентную, социальнуюориентированную рыночную экономику и ускорить евроинтеграцию.которые позволят создать современную конкурентную, социально- ориентированную рыночную экономику и ускорить евроинтеграцию. Практическая значимость. Таким образом, эффективная система государственных финансов, что является одним из главных факторов динамичного развития экономики формирует благоприятную макроэкономическую среду для предпринимательской деятельности и инвестиций, а также обеспечит надлежащую систему социальной защиты населения.

Ключевые слова: налоги, налоговая система, налоговая политика, налоговое бремя, реформирование системы налогообложения, европейская интеграция.

\section{Khoroshilova I. PATH INTEGRATION-TAX REFORM}

Purpose our research is in covering current European legislation on taxation and legislation and identifying priorities for the future concerning the transformation of the tax system in the context of the European integration. Methodology of research analysing, comparing, systematizing and summarizing scientific labours of many scientists, will ground and will outline the changes of tax legislation of Ukraine in the conditions of eurointegration, for this purpose succeeded to to ekonomiko statistical methods, comparative analysis. Findings the modern state and defects of domestic model of tax relations of Ukraine is analysed, certainly basic directions of its reformation and perfection. Taking into account signing of Agreement about the association of Ukraine and European Union which is large achievement and step of transformations and economic development. But economic integration and rapprochement from $\mathrm{ES}$ require from countries-applicants on the entry of implementation of a number of requirements, one of which there is a leadthrough of tax reforms with the purpose of harmonization of internal tax. Originality directions 
of optimization of taxation of Ukraine are outlined, namely an increase of role of the state is in a management and adjusting own financial resources, increase of volumes of GDP, which will enable to create the modern competition, social-oriented market economy and accelerate eurointegration. Practical value Thus, an effective system of public finance, which is one of the main factors of dynamic economic development creates a favorable macroeconomic environment for business activity and investment, as well as to ensure a proper system of social protection of the population.

Key words: taxes, tax system, tax policy, tax burden, reforming the tax system, European integration.

\section{Відомості про авторів}

Хорошилова Ірина Олександрівна - кандидат економічних наук, Харківський національний автомобільно-дорожній університет, доцент кафедри обліку, оподаткування та міжнародних економічних відносин, м. Харків, Україна; e-mail: hia23@ukr.net; ORCID ID: https://orcid.org/0000-00015343-5161. Моб. 050-307-97-03.

Хорошилова Ирина Александровна - кандидат экономических наук, Харьковский национальный автомобильно-дорожный университет, доцент кафедры учета, налогообложения и международных экономических отношений, г. Харьков, Украина.

Khoroshilova Irina - Candidate of Sciences (Economics), Kharkov National Automobile and Highway University, Associate Professor at the Department of account, taxation and international economic relations, Kharkiv, Ukraine. 